\title{
AKULTURALIZM KARY ŚMIERCI W ŚWIETLE PEDAGOGIKI I TEOLOGII
}

Każdy ma prawo do życia, wolności i bezpieczeństwa osobistego Powszechna Deklaracja Praw Człowieka i Obywatela, 1948.

[...] Nikt nie może być arbitralnie pozbawiony życia International Covenant on Civil and Political Rights, 1978.

Życie człowieka pochodzi od Boga, [...] człowiek nie może nim rozporządzać EV 39 .

\section{WPROWADZENIE}

Nie istnieją społeczeństwa, w których nie zdarzają się przestępstwa i dlatego nie zachodziłaby w nich potrzeba karania kogokolwiek. Badania dowodzą, że nawet w najbardziej pierwotnych społeczeństwach istniało przekonanie zależności między winą a karą. Wraz z ewolucją społecznej świadomości ta zależność się umacniała i pogłębiała, toteż systematycznie podnoszony jest problem winy i kary.

Ks. dr hab. Kazimierz Pierzchala, prof. nadz. KUL, dr teologii biblijnej, dr hab. pedagogiki resocjalizacyjnej - Katedra Pedagogiki Ogólnej, Instytut Pedagogiki, Wydział Nauk Społecznych, Katolicki Uniwersytet Lubelski Jana Pawła II, Al. Racławickie 14, 20-950 Lublin; e-mail: kazimierz.pierzchala@kul.pl; ORCID:0000-0001-9972-943X 
Kulturalizm - to pogląd na świat; twórcą tego nurtu jest Florian Znaniecki ${ }^{1}$, polski filozof i socjolog. Pojęcia „kulturalizm” używał i je rozbudował również późniejszy polski filozof, Jan Stachniuk².

\begin{abstract}
Akulturacja - jest terminem stosowanym w naukach społecznych (np. w antropologii, etnologii, pedagogice, psychologii, socjologii) oraz w naukach o zarządzaniu (m.in. w zarządzaniu międzykulturowym, kulturze organizacji). W socjologii Akulturacja oznacza ,proces przejmowania przez grupę społeczną wzorów kultury innej grupy, w wyniku ich ciągłych i bezpośrednich kontaktów, co prowadzi do upodobnienia się wzorów kulturowych obu tych grup" (Bańko, 2014).
\end{abstract}

Akulturacja - według Ireny Parfieniuk (2009) - jest procesem zmian w związku z długim kontaktem jednostki z obcą kulturą, obejmuje wszystkie aspekty funkcjonowania człowieka, jest zbiorem nowych i trudnych doświadczeń. Można ją rozpatrywać na dwóch poziomach: grupowym i indywidualnym. Poziom grupowy odnosi się do zmian w obrębie struktur społecznych $i$ instytucjonalnych oraz praktyk kulturowych. Na poziomie indywidualnym akulturacja prowadzi do zmian w repertuarze zachowań jednostki, ale także jej tożsamości, np. budując nowy system wartości.

W pedagogice akulturacja określa mechanizm przejmowania kultury „obcej”, polegający na przyswajaniu przez jedną grupę elementów kultury drugiej grupy poprzez kontakt społeczny. Te elementy kultury to na przykład: wartości, normy zachowania, sposoby myślenia. Akulturacja zachodzi między odrębnymi, ukształtowanymi w odmiennych warunkach, systemami społeczno-kulturowymi i prowadzi najczęściej do zaniku wszystkich lub części elementów jednej kultury (mniejszościowej, nie dominującej) (Pilch, 2003). Poprzez akulturację w osobowości ludzkiej mogą zachodzić zmiany. Zmiana osobowości zaś stanowi

${ }^{1}$ Florian Znaniecki - jeden z pierwszych badaczy zjawiska akulturacji. Badał on imigrantów z Polski przybyłych do Stanów Zjednoczonych w pierwszej połowie XIX wieku (Znaniecki, 2001/1934). W swoich badaniach skupił się na charakterystyce procesów dezorganizacji społecznej, ale też przemian pozytywnych, jakie obserwował wśród osiedlających się emigrantów polskich w Stanach Zjednoczonych. Zgodnie z nim, przedmiotem nauk o kulturze powinno być świadome, subiektywne odzwierciedlenie (np. źródłem danych empirycznych powinny być pamiętniki). We wspólnej z Williamem I. Thomasem w pięciotomowej pracy Polski chłop w Europie $i w$ Stanach (1918-1920) źródłem danych empirycznych były listy pisane do kraju (Thomas, Znaniecki, 1976; Boski, 2009).

${ }^{2}$ Jan „Stoigniew” Stachniuk (1905-1963) - polski filozof i publicysta. Teoretyk i twórca idei kulturalizmu, a także redaktor naczelny przedwojennego, nacjonalistycznego pisma „Zadruga” oraz lider skupionego wokół niego ruchu o tej samej nazwie. 
istotę wychowania. Skoro akulturacja może wywoływać zmiany w osobowości, to może też wspomagać procesy wychowania oraz resocjalizacji.

Resocjalizacja - według Kazimierza Pierzchały (2017b, s. 95), byłego kapelana więziennego - to nauka i praktyka społeczna, określająca zakres działań wychowawczych, opiekuńczych i terapeutycznych. Jest to proces zmierzający do wykształcenia u osób niedostosowanych społecznie zmian w obszarze samoświadomości, samowychowania, samopotwierdzenia i samorefleksyjności.

\section{Z teologicznego punktu widzenia}

akulturacja (ang. acculturation) - według Zbigniewa Stachowskiego - to proces kulturowy [...] prowadzący w efekcie do rozpadu i wchłonięcia kultury podporządkowanej. Proces akulturacji, zmierzający do hegemonii kultury „wniesionej” nad kulturą „,zastaną”, zwykle przebiega dość szybko i może dokonać się za życia jednego pokolenia. Akulturacji często towarzyszą procesy retardacyjne [opóźnienie rozwoju - K.P.], które prowadzą do okresowej rewitalizacji kultury zdominowanej, a są wywołane albo tęsknotą za utraconymi wzorami kultury, albo rozczarowaniem narzuconymi wartościami. Nową strategią we współczesnym urzeczywistnianiu celów akulturacyjnych jest inkulturacja (inaczej akomodacja, socjol. stopniowy proces wrastania jednostki w kulturę otaczającego ją społeczeństwa) (Stachowski, 2004a; por. Nowicka, 1998).

W koncepcji inkulturacji, znaczeniowo związanej z terminem „akulturacja”, chodzi o kultywowanie i przekazywanie dziedzictwa kulturowego oraz o możliwość przepojenia kultur rodzimych kulturowymi zwyczajami i wzorcami chrześcijaństwa. W koncepcji tej, rozwijanej w okresie pontyfikatu Jana Pawła II, ma się na uwadze proces „zakorzenienia” $\mathrm{i}$ „wszczepienia” Ewangelii i wiary w określonych kulturach, o przemianę owych kultur od wewnątrz, a nie od zewnątrz (akulturacja) (Stachowski, 2004b).

Celem artykułu jest próba ukazania akulturalizmu stosowania kary śmierci poprzez przejmowanie obcej kultury (zasad) między Europą a resztą świata, w tym Stanami Zjednoczonymi, akulturalizmu kary śmierci w świetle dwóch nauk: pedagogiki i teologii. Artykuł próbuje odpowiedzieć na pytania: Jak akulturacja może wpływać na doktrynę kary śmierci w przyszłości? Co może i ile wpłynąć na decyzje poszczególnych państw? Jaki wpływ na stosowanie kary śmierci ma nauka Kościoła? Czy akulturalizm mógł wpłynąć na prawodawstwo kościelne? Autor artykułu stawia tezę, iż papież Jan Paweł II istotnie przyczynił się do zmiany stanowiska Kościoła katolickiego w kwestii stosowania w prawodawstwie kary śmierci. 
Metodologią zastosowaną przy pisaniu przedmiotowej publikacji stało się przeprowadzenie krytycznej analizy literatury, aktów prawnych i innych dokumentów, zarówno świeckich, jak i kościelnych, w tym dostępnych zasobów internetowych: polskich i zagranicznych.

Wielka Encyklopedia Nauczania Jana Pawła II z 2014 roku podaje następującą definicję kary śmierci:

Kara śmierci - najwyższy wymiar kary za najpoważniejsze przestępstwa przeciwko życiu. W czasach Starego Testamentu, w celu zachowania Przymierza z Bogiem, była stosowana za wykroczenia przeciwko życiu, wierze, seksualności oraz występki wobec rodziców. W tekstach starożytnych pisarzy chrześcijańskich uważano ją za sprzeczną z wiarą chrześcijańską. Od uchwalenia Edyktu mediolańskiego (313 rok) ${ }^{3}$ była coraz powszechniej akceptowana jako jedna $\mathrm{z}$ form instytucjonalnych państwa, choć wierzący mieli zakaz uczestnictwa w jej wymierzaniu i wykonywaniu. Uzasadnienie kary śmierci potrzebą obrony zagrożonego dobra wspólnego, pochodzące od św. Tomasza z Akwinu, zostało - przy nielicznych głosach sprzeciwu - przejęte przez teologów. W latach 80. i 90. XX wieku karę śmierci zniesiono w ustawodawstwie wielu krajów świata (Glombik, Nitecki, 2014).

Kara śmierci. Nie ulega wątpliwości, że jest ona najsurowszą i najstarszą, stosowaną prawie we wszystkich kulturach świata karą, legalnie lub nielegalnie, zarówno w starożytności, jak i współcześnie. Kara śmierci stosowana była już w starożytności w: Babilonii, Izraelu, Asyrii, Grecji, Rzymie. W Starym Testamencie obowiązywało prawo Mojżesza: „Kto zabije człowieka, będzie ukarany śmiercią” (Kpł 24, 21) lub w innym miejscu: „[Jeśli] kto przeleje krew ludzką, przez ludzi ma być przelana krew jego, bo człowiek został stworzony na obraz Boga" (Rdz 9, 6). Karze śmierci podlegały takie przestępstwa, jak: bałwochwalstwo, bluźnierstwo, niezachowanie szabatu, uprawianie magii, a nawet cudzołóstwo i sodomia (Pierzchała, 2008, s. 25-27).

Obecnie w Stanach Zjednoczonych stosuje się bardziej „humanitarne” środki, takie jak śmiertelny zastrzyk czy porażenie prądem. Karanie śmiercią, podobnie jak środki zarządzania karą śmierci, ewoluowały w miarę upływu czasu, podobnie jak postawy wobec kary śmierci. W ubiegłym stuleciu Sąd Najwyższy Stanów Zjednoczonych zrewidował doktrynę dotyczącą kary śmierci,

${ }^{3}$ Edykt mediolański (łac. Edictum Mediolanense) - edykt ogłoszony wspólnie przez cesarza zachodniej części Imperium Rzymskiego Konstantyna Wielkiego oraz cesarza wschodniej części Licyniusza w 313 roku w Mediolanie. Zaprowadzał wolność wyznania wiary w Cesarstwie Rzymskim. Od tej pory chrześcijanie bez przeszkód mogli wyznawać swoją religię. Na mocy edyktu nastąpił zwrot budynków i gruntów kościelnych gminom chrześcijańskim (Edykt, 313). 
wykazując obawy związane z tym, kiedy i w stosunku do kogo jest stosowana oraz w jaki sposób jest ona wykonywana. Doktryna kary śmierci w Stanach Zjednoczonych niemal zawsze podążała śladami rozwoju kary śmierci w innych rozwiniętych zachodnich demokracjach.

Również Kościół katolicki sankcjonował karę śmierci przez wiele wieków, współpracując z władzami świeckimi, zwłaszcza przy zwalczaniu „heretyków”. Inkwizycja (instytucja Kościoła katolickiego powołana w XII w. przez papieża do zwalczania herezji, „później przejęta także przez niektóre Kościoły protestanckie", stosująca tortury, zniesiona w XIX w.) przesłuchiwała oskarżonych, wydawała wyroki, natomiast władza świecka je wykonywała. Kara śmierci była silnym instrumentem w sprawowaniu władzy w każdym systemie ustrojowym i niestety - jak uczy historia - okrutnie nadużywanym w majestacie prawa. Zasadność i prawomocność stosowania kary śmierci zaczęto podważać w XX stuleciu. Prawnicy argumentowali, że nie musi być ona koniecznym i wyłącznym środkiem realizacji sprawiedliwości dla zachowania porządku społecznego. Za jej zniesieniem były wszystkie państwa Unii Europejskiej, w których obecnie tej kary nie ma, a najwyższą karą pozostało dożywocie. Kara śmierci jest nadal wykonywana w państwach islamskich, Rosji i niektórych Stanach Zjednoczonych Ameryki Północnej.

Zdolność wpływania na zachowanie państwa w dziedzinie praw człowieka tradycyjnie jest rozumiana poprzez ramy składające się z dwóch metod: przymusu i perswazji. Jednak te dwie metody nie wydają się w pełni wyjaśniać zmian w doktrynie kary śmierci, np. w Stanach Zjednoczonych. W kraju tym środki przymusu stosowano rzadko, a wpływ bezpośrednich prób przekonywania USA do zmiany doktryny kary śmierci jest wątpliwy. Jest więc prawdopodobne, że inna, mniej oczywista metoda oddziaływania jest w tym obszarze stosowana. W artykule zatytułowanym Jak wpływać na państwa: socjalizacja i międzynarodowe prawo dotyczace praw człowieka (Goodman, Jinks, 2004, s. 626) profesorowie Ryan Goodman i Derek Jinks analizowali teorię w kontekście rozpowszechniania międzynarodowego prawa człowieka. Badali, czy odbywa się to za pomocą środków przymusu, czy perswazji, dochodząc do wniosku, że metodą tą jest akulturacja (Goodman, Jinks, 2004, s. 626). Podkreślają oni, że akulturacja wymusza zmiany zachowań poprzez naciski na asymilację (przystosowanie się do życia w obcej grupie przez przejęcie jej kultury i przyswojenie sobie cech właściwych tej grupie; także wchłonięcie obcej grupy) niektóre narzucane przez inne podmioty, a niektóre przez siebie (Goodman, Jinks, 2004, s. 626). Akulturacja ich zdaniem pomaga w pełniejszym stopniu wyjaśnić podobieństwa między doktryną kary śmierci w Europie i na świecie (Patterson, 2006). 


\section{DOKTRYNA KARY ŚMIERCI W EUROPIE}

Pierwsze próby zniesienia kary śmierci w Europie miały miejsce pod koniec XVIII w. Przed tym okresem kara śmierci była powszechnie stosowana w Europie za pomocą różnych barbarzyńskich środków. Jednakże wzrost filozofii humanitarnej pod koniec XVIII w. spowodował, że praktycy i teoretycy przewartościowali swoje traktowanie osób uznanych za winnych przestępstw. Przywódcy państwowi zaczęli rozwijać bardziej humanitarne systemy prawa karnego pod wpływem takich filozofów, jak m.in. Cesare Beccaria, który krytykował karę śmierci w swoim traktacie O przestępstwach $i$ karach (1764) (Beccaria, 2014). W tym duchu kilka państw wzywało do zniesienia kary śmierci, m.in. Toskania, Austria i Francja ${ }^{4}$.

Ruch abolicjonistyczny (ruch społeczny domagający się zniesienia jakiegoś prawa; w XVIII-XIX w. w Europie i obu Amerykach działający na rzecz zniesienia niewolnictwa i dyskryminacji rasowej), który wystąpił w Europie pod koniec XVIII w., był bardzo silny, ale krótkotrwały. Wkrótce po uchwaleniu przepisów o zniesieniu kary śmierci zostały one cofnięte. Francuski kodeks cywilny, który posłużył za podstawę kodeksów w Belgii, Holandii i Luksemburgu, wskazywał wykonywanie kary śmierci jako kary za konkretne zbrodnie. Ponadto kara śmierci stanowiła karę za ponad 200 przestępstw w Anglii na przełomie XIX i XX w. (Ancel, 1962, s. 9). Dopiero wiek XIX dostarczył stopniowe ograniczenie zasięgu kary śmierci. Sytuacja ta wynikła ze zmniejszenia liczby przestępstw zagrożonych karą śmierci, a ponadto przez stopniowe, coraz rzadsze jej orzekanie w praktyce sądowej. Większość przypadków całkowitego jej zniesienia miała miejsce dopiero jednak w XX w.

Kolejne niepowodzenia w całkowitym zniesieniu kary śmierci w Europie powtórzyły się w pierwszej połowie XX w. Ruchy autorytarne (oparte na bezwzględnym posłuszeństwie wobec władzy) wpłynęły na to, że wiele krajów przywróciło karę śmierci, m.in. Włochy, Austria i Niemcy (w których prawo niemieckie obowiązywało w latach 1938- 1945; tzw. nazizm). Ponadto II wojna światowa spowodowała, że nawet państwa o silnym kierunku abolicjonistycznym przywróciły karę śmierci za zbrodnie wojenne (Ancel, 1962, s. 11-12). Pomimo tych niepowodzeń, tendencja do zniesienia kary śmierci w Europie

\footnotetext{
${ }^{4}$ Leopold II z Toskanii zniósł karę śmierci w toskańskim kodeksie karnym z 1786 roku, a Józef II zlikwidował ją w austriackim kodeksie z 1787 r. W odniesieniu do prawa francuskiego należy zauważyć, że dekret Konwencji of 14th Brumaire of the Year IV przewidywał zniesienie kary śmierci, gdy zostanie przywrócony pokój, ale nigdy nie przyjął skutku, nawet po zawarciu 25 marca 1802 roku pokoju w Amiens między Francją a Zjednoczonym Królestwem Wielkiej Brytanii i Irlandii (Ancel, 1962, s. 9).
} 
była kontynuowana po zakończeniu II wojny światowej. Od 1962 r. tylko Wielka Brytania, Republika Irlandii, Hiszpania, Turcja, Grecja i Francja przeprowadziły egzekucje w Europie, a do 1977 r. już tylko Turcja była jedynym państwem, która nie zaniechała stosowania kary śmierci. Ruch w kierunku zniesienia kary śmierci można było nawet zaobserwować w krajach byłego Związku Radzieckiego, znanego wcześniej z częstego stosowania kary śmierci, zwłaszcza pod koniec lat 80. XX stulecia, jako narzędzia politycznego (Hood, 1999, s. 10).

W Polsce obecnie nie wykonuje się kary śmierci. Ostatnia publiczna egzekucja miała miejsce 21 lipca 1946 r. w Poznaniu, gdzie na stokach cytadeli powieszono nazistowskiego zbrodniarza Arthura Greisera, hitlerowskiego namiestnika tzw. Kraju Warty. Wyrok wydał Najwyższy Trybunał Narodowy 5 . Straconego poddano kremacji, a jego prochy rozsypano w nieznanym miejscu (70 lat temu na szubienicy zawist). W Polsce ostatni wyrok kary śmierci wykonano 21 kwietnia 1988 r. w krakowskim więzieniu przy ul. Montelupich na Stanisławie Czabańskim, skazanym za brutalny gwałt i zamordowanie kobiety w Tarnowie (Ostatni wyrok śmierci w PRL). Łącznie w latach 1956-1988 w PRL stracono 321 osób (Pademski, 2001).

Tendencji do zniesienia kary śmierci w poszczególnych krajach europejskich w drugiej połowie XX w. towarzyszył rozwój ruchów upowszechniających stosowanie praw człowieka, z których wiele popierało zniesienie tej kary. Pierwszym ważnym krokiem w kierunku budowy międzynarodowego systemu praw człowieka, w tym zniesienia kary śmierci w skali międzynarodowej, było przyjęcie przez ONZ Powszechnej Deklaracji Praw Człowieka (dalej: UDHR) w 1948 r. ${ }^{6}$ Artykuł 3 UDHR stanowi, że: „Każdy ma prawo do życia, wolności i bezpieczeństwa osobistego". Chociaż przepis ten stanowczo nie nakłaniał do zniesienia kary śmierci, to jednak stwierdzenie „ma prawo do życia” stanowiło ważny argument dla przyszłych wydarzeń (Patterson, 2006, s. 1221).

\footnotetext{
${ }^{5}$ Najwyższy Trybunał Narodowy - polski sąd szczególny, utworzony 18 lutego 1946 r. i działający na podstawie Dekretu z dnia 22 stycznia 1946 r. o Najwyższym Trybunale Narodowym (Dz. U. 1946, nr 5, poz. 45), zajmujący się wymierzaniem kar dla faszystowsko-hitlerowskich zbrodniarzy oraz zdrajców Narodu Polskiego. Trybunał procedował w latach 1946-1948 (Jakubowski, 2002, s. 37; Kallas, 2001, s. 496).

${ }^{6}$ Powszechna Deklaracja Praw Człowieka (Universal Declaration of Human Rights) znaczy dosłownie ,prawa ludzkie” - zbiór praw człowieka i zasad ich stosowania uchwalony przez Zgromadzenie Ogólne ONZ rezolucją 217/III A w dniu 10 grudnia 1948 r. w Paryżu. W następstwie tego historycznego wydarzenia Zgromadzenie Ogólne wezwało państwa członkowskie do opublikowania tekstu Deklaracji i do „spowodowania, aby Deklaracja była rozpowszechniana, pokazywana, czytana i objaśniana przede wszystkim w szkołach i innych instytucjach oświatowych, wszędzie bez względu na status polityczny kraju lub terytorium" (część D, punkt 1).
} 
Treści te można znaleźć w kolejnym ważnym dokumencie, dotyczącym rozwoju międzynarodowego prawa człowieka, tj. w Międzynarodowym Pakcie Praw Obywatelskich i Politycznych (dalej: ICCPR) (International, 1976). ICCPR opiera się na UDHR, dodając szczegóły i zapewniając wiążące normy. Artykuł 6 ICCPR stanowi, że

1. Każda istota ludzka ma przyrodzone prawo do życia. Prawo to powinna ochraniać ustawa. Nikt nie może być arbitralnie pozbawiony życia [wyróżn. K.P.].

2. W krajach, w których kara śmierci nie została zniesiona, wyrok śmierci może być wydany jedynie za najpoważniejsze przestępstwa, zgodnie z prawem, które obowiązuje w chwili popełnienia przestępstwa i które nie powinno pozostawać w sprzeczności z postanowieniami niniejszego Paktu ani konwencji o zapobieganiu i karalności zbrodni ludobójstwa. Kara ta może być wykonywana tylko na mocy prawomocnego wyroku wydanego przez właściwy sąd.

3. W przypadku, gdy pozbawienie życia stanowi zbrodnię ludobójstwa, jest oczywiste, że żadne postanowienie niniejszego artykułu nie upoważnia żadnego Państwa-Strony niniejszego Paktu do uchylenia w żaden sposób zobowiązania przyjętego na mocy postanowień konwencji o zapobieganiu i karaniu zbrodni ludobójstwa.

4. Każdy skazany na śmierć ma prawo ubiegać się o ułaskawienie lub zmianę kary. Amnestia, ułaskawienie lub zmiana kary mogą być zastosowane w każdym przypadku.

5. Wyrok śmierci nie będzie stosowany za przestępstwa popełnione przez osoby w wieku poniżej lat 18 i nie będzie wykonywany na kobietach ciężarnych.

6. Nie wolno powoływać się na żadne postanowienia niniejszego artykułu w celu opóźnienia lub przeszkodzenia w zniesieniu kary śmierci przez Państwo-Stronę niniejszego Paktu (Michalska, 1984, s. 74).

Chociaż ICCPR nie zabraniał stosowania kary śmierci, z wyjątkiem osób w wieku poniżej osiemnastu lat w chwili popełnienia przestępstwa i kobiet w ciąży, artykuł 6 stwierdza: „Nie wolno powoływać się na żadne postanowienia niniejszego artykułu w celu opóźnienia lub przeszkodzenia w zniesieniu kary śmierci przez Państwo-Stronę niniejszego Paktu". Sformułowanie artykułu 6 wskazało zatem na preferencję zniesienia kary śmierci.

Drugi Protokół Fakultatywny do ICCPR stanowił ponadto, że

1. Wobec żadnej osoby pozostającej pod jurysdykcją Państwa-Strony niniejszego Protokołu nie wykona się kary śmierci. 
2. Każde Państwo-Strona podejmie wszelkie niezbędne środki celem zniesienia kary śmierci w ramach własnej jurysdykcji (art. 1).

Chociaż Drugi Protokół Fakultatywny do ICCPR był wiążący tylko dla tych państw, które go ratyfikowały, stanowiło to pierwszy krok do powstania międzynarodowej normy przeciwko karze śmierci. Ponadto uchwalona Konwencja o prawach dziecka z 20.11.1989 r. (dalej: CRC) wskazuje, że każde dziecko, a więc każda istota ludzka w wieku poniżej osiemnastu lat (chyba że wcześniej uzyska pełnoletność), ma prawo do życia.

Prawo do życia zostało wyrażone również w aktach międzynarodowych o regionalnym charakterze. Można w nich zauważyć, że wzorują się one na postanowieniach Powszechnej Deklaracji Praw Człowieka i ICCPR. W Karcie Praw Podstawowych Unii Europejskiej z 7.12.2000 r. zapisano dosyć lapidarnie w art. 2 , że , ,... [ każdy ma prawo do życia. Nikt nie może być skazany na karę śmierci ani poddany jej wykonaniu [wyróżn. K.P.]”.

Rozwój światowego systemu praw człowieka doprowadził do ogólnoeuropejskiego zniesienia kary śmierci, towarzysząc międzynarodowym zmianom w tym zakresie. Pierwszym ważnym krokiem w rozwoju europejskiego systemu praw człowieka było stworzenie Europejskiej Konwencji Praw Człowieka (ECHR). Rada Europy uchwaliła ECHR, która weszła w życie 3 września 1953 r., tworząc listę podstawowych praw i wolności podlegających jurysdykcji Europejskiego Trybunału Praw Człowieka. Artykuł 2 ECHR stwierdza, że „prawo każdego [człowieka - K.P.] do życia jest chronione przez ustawę" (art. 2, ust. 1). Jednakże ECHR nie zniosła zupełnie kary śmierci, stwierdzając:

Nikt nie może być umyślnie pozbawiony życia, wyjąwszy przypadki wykonania wyroku sądowego, skazującego za przestępstwo, za które ustawa przewiduje taką karę [wyróżn. K.P.] (art. 2, ust. 1).

Zapisy te uwzględniają także instytucję „obrony koniecznej” i nie tylko, podając, że

2. Pozbawienie życia nie będzie uznane za sprzeczne z tym artykułem, jeżeli nastąpi w wyniku bezwzględnie koniecznego użycia siły:

a) w obronie jakiejkolwiek osoby przed bezprawną przemocą;

b) w celu wykonania zgodnego z prawem zatrzymania lub uniemożliwienia ucieczki osobie pozbawionej wolności zgodnie z prawem;

c) w działaniach podjętych zgodnie z prawem, w celu stłumienia zamieszek lub powstania (art. 2, ust. 2). 
Pod koniec lat 70. Komitet Ministrów Rady Europy ${ }^{7}$ zaczął uznawać karę śmierci za kwestię praw człowieka. Gdy Rada Europy uznała, że kara śmierci narusza prawa człowieka, podjęto decyzję o zmianie prawa w całej Unii Europejskiej. Komitet Ministrów postanowił przyjąć Protokołem do Europejskiej Konwencji o Ochronie Praw Człowieka i Podstawowych Wolności prawo, które zakazało wykonywania kary śmierci w krajach europejskich. Protokół 6 do ECHR został opracowany i wszedł w życie 1 marca 1985 r. (Protokół 6; Patterson, 2006, s. 1223).

Protokół 6 do ECHR był pierwszą ogólnoeuropejską deklaracją w sprawie zniesienia kary śmierci. Artykuł 1 ww. Protokołu stanowi, że: „Znosi się karę śmierci. Nikt nie może być skazany na taką karę ani nie może nastąpić jej wykonanie [wyróżn. K.P.]" (art. 1). Protokół ten bezpośrednio zakazał wykonywania kary śmierci, nie wymagając żadnych działań ze strony państw. Należy jednak zauważyć, że chociaż Protokół 6 był dużym krokiem w kierunku zniesienia kary śmierci w Europie, to nadal zapewniał państwom członkowskim możliwość stosowania kary śmierci w czasie wojny (art. 2).

Kolejny ważny krok w kierunku zniesienia kary śmierci w Europie nastąpił, gdy Rada Europy zdecydowała w 1993 r., że kandydaci do Rady muszą podpisać i ratyfikować ECHR (Hood, 1999, s. 11). W 1994 r. Zgromadzenie Parlamentarne wzmocniło ten wymóg, stwierdzając, że Rada musi wprowadzić natychmiastowe moratorium na egzekucje, a następnie podpisać i ratyfikować Protokół 6 do ECHR, znosząc karę śmierci w czasie pokoju (Hood, 1999, s. 11). Tak więc wszyscy członkowie Rady Europy byli zobowiązani do zniesienia kary śmierci w czasie pokoju. W 2002 r. Rada Europy przyjęła Protokół 13 do ECHR (Protokół, 2014), który uzupełnia Protokół 6, wzywając do całkowitego zniesienia kary śmierci, nawet w czasie wojny. Ponadto, aby stać się członkiem Unii Europejskiej (UE), państwo musiało znieść karę śmierci (Hood, 1999, s. 11). Dodatkowo UE podjęła działania mające na celu nakłonienie innych państw do zniesienia kary śmierci, w tym wydała wytyczne w sprawie polityki UE wobec krajów trzecich na temat kary śmierci (Wytyczne, 1998).

Europa od wieków dążyła do zniesienia kary śmierci. Po okresie abolicjonizmu nastąpiło zahamowanie tych dążeń - do czasu powstania w drugiej połowie XX wieku międzynarodowego trendu aktywnie nakierowanego na ochronę praw człowieka, co spowodowało gwałtowny ruch Europy w kierunku zniesienia kary śmierci. Stany Zjednoczone ciągle stoją przed ostatecznym

\footnotetext{
${ }^{7}$ Komitet Ministrów Rady Europy - jedyny organ decyzyjny Rady Europy. Skupia ministrów spraw zagranicznych państw członkowskich. Ważne decyzje podejmuje jednomyślnie, przyjęcie nowych członków zatwierdza większością 2/3 głosów, inne decyzje - bezwzględną większością.
} 
krokiem całkowitego jej zniesienia, niemniej jednak sam rozwój amerykańskiej doktryny dotyczącej kary śmierci podążał bardzo podobną ścieżką do europejskich wydarzeń.

\section{AKULTURACJA STOSOWANIA KARY ŚMIERCI WEDŁUG RYANA GOODMANA I DEREKA JINKSA}

Aby zrozumieć, dlaczego doktryna kary śmierci w Stanach Zjednoczonych rozwinęła się podobnie jak w Europie, należy rozpocząć od wyjaśnienia tego, w jaki sposób w ogóle państwa wpływają nawzajem na siebie. Ryan Goodman i Derek Jinks wytyczyli ramy szczególnie w dziedzinie praw człowieka (Goodman, Jinks, 2004, s. 625-626). Teoria Goodmana i Jinksa stanowi podstawę do zrozumienia czynników, które ukształtowały doktrynę amerykańskiej kary śmierci. W ramach tej teorii istnieją trzy mechanizmy, za pomocą których państwa wpływają na siebie nawzajem; są to: przymus, perswazja i akulturacja. Ze względu na temat artykułu szerzej zostanie omówiony tylko trzeci mechanizm, który jest niezbędny do pełniejszego zrozumienia, w jaki sposób państwa wpływają na siebie nawzajem. Mechanizm określony jako akulturacja jest ważnym, choć niedocenianym mechanizmem społecznym i działa nie przez bezpośredni wpływ (jak przymus czy perswazja), ale zamiast tego (Patterson, 2006, s. 1232).

Od samego początku było jasne, że doktryny kary śmierci zarówno w Europie, jak i w Stanach Zjednoczonych działają na podobnej trajektorii. Tak jak Europa przeszła długi okres stopniowego przemieszczania się w kierunku zniesienia kary śmierci, co było naznaczone szeregiem przejściowych niepowodzeń, zanim całkowicie zniosła karę śmierci, tak i Stany Zjednoczone doświadczają różnych tendencji do zniesienia kary śmierci (przez orzecznictwo Sądu Najwyższego), pomimo wielu niepowodzeń.

Stany Zjednoczone podążają śladami Europy nie (tylko) w wyniku bezwzględnego przymusu i perswazji, ale przede wszystkim dzięki akulturacji.

\subsection{PRZYMUS I PERSWAZJA}

Do przymusowych środków, które Europa i inne państwa stosowały przeciwko Stanom Zjednoczonym w związku z wykonywaniem kary śmierci, zaliczyć można groźby ekonomiczne. Europa przyjęła zasadę, że nie inwestuje w państwach, które stosują karę śmierci, a ponadto, że może odmówić z tego 
samego powodu ekstradycji przestępców do Stanów Zjednoczonych (Dugard, Wyngaert, 1998). Chociaż europejska odmowa inwestowania byłaby kosztowna dla Stanów Zjednoczonych ekonomicznie, a odmowa ekstradycji odebrałaby Stanom Zjednoczonym możliwość ścigania oskarżonych przestępców w ramach swojej jurysdykcji, to jednak siła gospodarcza i polityczna Stanów Zjednoczonych zmniejsza potencjalny wpływ tych kosztów. Środki te wydają się mało prawdopodobne, aby zasadniczo zmienić zachowanie Stanów Zjednoczonych (Patterson, 2006, s. 1236).

Bardziej znaczącymi środkami przymusu w odniesieniu do stosowania kary śmierci są międzynarodowe traktaty, takie jak ICCPR i jego Drugi Protokół oraz CRC, podpisane przez wiele państw, z których wszystkie zawierają przepisy dotyczące kary śmierci. Stany Zjednoczone ratyfikowały ICCPR, z zastrzeżeniem dotyczącym dalszego stosowania kary śmierci, nie ratyfikując Drugiego Protokołu do ICCPR oraz CRC. Traktaty te są jednak względnie słabymi zachętami dla Stanów Zjednoczonych do zmiany zachowania. Europa zaś boi się stracić olbrzymi rynek zbytu, dlatego też jej naciski są mało skuteczne.

Próby Europy nakłonienia Stanów Zjednoczonych do pójścia w jej ślady w zakresie zniesienia kary śmierci rozpoczęły się wraz ze sformułowaniem Wytycznych dla polityki Unii Europejskiej wobec krajów trzecich w sprawie kary śmierci w 1989 r. (1998), które nakreśliły dążenie UE do zniesienia kary śmierci. Wkrótce po tym dokumencie UE rozpoczęła składanie serii oświadczeń, listów, depesz itp. do Stanów Zjednoczonych w celu zachęcenia ich do zniesienia kary śmierci lub przynajmniej ograniczenia jej użycia. Jednak pomimo długiej listy przypadków, w których wydaje się, że europejskie i międzynarodowe próby perswazji przyniosły efekt, istnieje uzasadnione przypuszczenie, że próby te nie były skuteczne ze względu na przekonanie odbiorcy. Stany Zjednoczone tego nie zrobiły, ponieważ czuły się przekonane o prawdzie i słuszności swojego działania (Patterson, 2006, s. 1239).

\subsection{DZIAŁANIE AKULTURACJI}

Fakt, że Stany Zjednoczone i Europa mają podobny poziom poszanowania praw człowieka w obszarach innych niż kara śmierci, pozwala obu regionom postrzegać siebie jako narody, które szanują prawa człowieka. Stany Zjednoczone były od lat na czele ruchu, by tworzyć międzynarodowe trendy, aby globalnie szanować prawa człowieka. Poszanowanie praw człowieka jest ukryte w tożsamości i społecznej roli Stanów Zjednoczonych. Uważają się one za kraj, który szerzy prawa człowieka, a nie taki, który je narusza. Coraz większa 
determinacja, z jaką Europa próbuje przekonać Stany Zjednoczone i inne kraje do porzucenia kary śmierci, tworzy znaczną presję wzmacniającą dysonans. Europa usiłowała również stworzyć różne korzyści społeczno-psychologiczne dla Stanów Zjednoczonych, aby kontynuować swoją trajektorię na tej samej ścieżce, co Europa w doktrynie kary śmierci (Patterson, 2006, s. 1242). Aby Stany Zjednoczone utrzymały swój status jako jednego ze światowych liderów w poszanowaniu praw człowieka, dostosowując się do środowiska społecznego w innych rozwiniętych zachodnich demokracjach, muszą zmierzać w kierunku całkowitego zniesienia kary śmierci.

\subsection{WZAJEMNE PRZENIKANIE SIĘ KOŚCIOŁA I PAŃSTWA}

Akulturacja w teologii to wzajemne przenikanie się Kościoła i państwa, sfery religijnej i cywilnej. Przenikanie się państwa i Kościoła w historii Polski było i jest bardzo mocno widoczne, a te dwie rzeczywistości są ze sobą - mimo licznych prób zmiany - ściśle związane. Polskość i chrześcijaństwo wypracowały związek, pozostając w ścisłej relacji subtelnego zjednoczenia, które nawet w chwilach próby dawało oparcie i wzmocnienie walki o narodowy byt. Wyjątek stanowiły czasy komunistycznych rządów. Dzięki troskliwości wielkiego Polaka i papieża Jana Pawła II udało się wznowić stosunki dyplomatyczne między Watykanem a Warszawą. O doniosłości tych wzajemnych relacji, w okolicznościach głębokich przemian dokonujących się w Polsce, dowodzą osiągnięcia w dziedzinie poszanowania ludzkiej godności i praw człowieka. Ten ważny aspekt został przedstawiony w dalszej części artykułu.

Stosunki te mogą być uregulowane w różnoraki sposób. Zagadnienie rozgraniczenia (lub złączenia) religii od państwa powinno odbywać się zgodnie z zapisami w konstytucji (lub innych aktach prawnych) danego kraju, które określają charakter państwa jako wyznaniowy lub laicki, a także wyznaczają miejsce religii w polityce państwa. Nie bez znaczenia w tej materii jest podpisany konkordat ${ }^{8}$, czyli umowa między władzą państwową a władzą kościelną.

Państwo i Kościół żyją obok siebie, lecz nie mogą być w pełni od siebie oddzielone, gdyż obejmują te same osoby - obywateli. Istnieją płaszczyzny życia, które są wspólne dla oddziaływania (akulturacji) państwa i Kościoła,

\footnotetext{
${ }^{8}$ Konkordat między Stolicą Apostolską i Rzeczpospolitą Polską - umowa międzynarodowa zawarta 28 lipca 1993 r. w siedzibie Rady Ministrów przez arcybiskupa Józefa Kowalczyka, ówczesnego nuncjusza apostolskiego w Polsce, i Krzysztofa Skubiszewskiego, ówczesnego ministra spraw zagranicznych Rzeczypospolitej Polskiej w rządzie Hanny Suchockiej (Konkordat, 1993).
} 
a próba ich rozdzielenia najczęściej kończy się tragicznie zarówno dla społeczeństw, którym odbiera się korzenie i tradycję, a które je ukształtowały, jak i dla władzy, dla której wolność religijna czasem rozumiana jest jako wolność od religii (Fec, 2016, s. 1).

Konstytucja Rzeczypospolitej Polskiej z 1997 roku, w art. 25 stanowi, że Kościoły i związki wyznaniowe są równouprawnione, a stosunki między państwem a Kościołami i innymi związkami wyznaniowymi są kształtowane na zasadach poszanowania ich autonomii oraz wzajemnej niezależności każdego w swoim zakresie, jak i współdziałania dla dobra człowieka i dobra wspólnego. Konstytucja stanowi również, że państwo zachowuje bezstronność w sprawach przekonań religijnych, światopoglądowych i filozoficznych, zapewniając swobodę ich wyrażania w życiu publicznym.

W Stanach Zjednoczonych Pierwsza Poprawka do Konstytucji z 1789 roku brzmi: „Żaden akt prawny nie może wprowadzić religii państwowej [...] ani zabronić jej swobodnego praktykowania" - i to powinno być kluczem akulturacji teologicznej z życiem publicznym.

Kara - według Jarosława Utrat-Mileckiego - [wyróżn. K. P.] to zjawisko w dziedzinie kultury i religii. Kulturowe uwarunkowania kary są uprzednie w stosunku do jej pojęcia w prawie, psychologii, pedagogice i filozofii. [...] W kulturze stanowi podstawę rozważań o karze - począwszy od pism Starego i Nowego Testamentu, filozoficznych traktatów starożytności, po wątki literatury pięknej we wszystkich epokach historycznych. [...] Kara za czyn jest możliwa tylko pod warunkiem, że człowiek ma wolną wolę. [...] Potępienie przemienia się w lekcję wychowawczą [...]. Doświadczenie winy, pokuty i przebaczenia nadaje religijny i społeczny kształt karze, oddzielając je od innych form represji i kontroli społecznej (Utrat-Milecki, 2004, s. 175-176).

Kara śmierci - to kara pozbawienia życia winowajcy. W rozumieniu teologiczno-etycznym, a także biologicznym życie jest najwyższą wartością, daną tylko raz. Nigdy też dokładnie nie wiemy, jaką wartość dla konkretnej osoby ma jego życie. Największym skarbem, jaki ma człowiek, jest jego życie. „Wszystko, co człowiek posiada, odda za swoje życie” (Hi 2, 4). 


\subsection{OKRES PRZED PONTYFIKATEM JANA PAWŁA II}

Odniesienie do kary śmierci na długie stulecia zakreśliła nauka św. Tomasza z Akwinu'. Jego bogaty dorobek intelektualny stał się fundamentem nauczania filozoficznego i teologicznego, a także związanym z nim doświadczeniem życia kościelnego. Św. Tomasz skomentował ten problem w ramach refleksji teologiczno-moralnej, odnoszącej się do cnoty sprawiedliwości (o której wiele pisał Joseph Ratzinger $)^{10}$, akredytując jej stosowanie oraz argumentując to stanowisko doktryną tzw. obrony własnej (por. STh I-II, q. 64). Jego umotywowanie opierało się na przekonaniu, że skoro społeczeństwo jest spójną całością, to wszystko, co nastaje na tę społeczność - a więc w tym przypadku także przestępca - może zostać dla jej dobra z niej usunięte (Nitecki, 2006).

Papieże - np. św. Innocenty I (402-417) i Innocenty III (1179-1180) czy w nowszych czasach Leon XIII (1878-1903), Pius XI (1922-1938) i Pius XII (1938-1958) - dopuszczali możliwość stosowania kary śmierci tylko w przypadkach najcięższych zbrodni. Odmienne stanowisko reprezentował papież Jan Paweł II, które zostało ujęte w zatwierdzonym przez Niego Katechizmie Kościoła Katolickiego (11 X 1992 r. - dalej cyt. KKK). Podaje on:

Jeśli środki bezkrwawe wystarczają do obrony życia ludzkiego przed napastnikiem i do ochrony porządku publicznego oraz bezpieczeństwa osób, władza powinna stosować te środki, gdyż są bardziej zgodne z konkretnymi uwarunkowaniami dobra wspólnego i bardziej odpowiadają godności osoby ludzkiej (KKK 2267; wyd. z 1994 r.) ${ }^{11}$.

9 Tomasz z Akwinu (Akwinata, łac. Thomas de Aquino, ur. ok. 1225 r., zm. 7 marca 1274 r.) - filozof scholastyczny, teolog, dominikanin. Był jednym z najwybitniejszych myślicieli w dziejach chrześcijaństwa. Święty Kościoła katolickiego, jeden z doktorów Kościoła, który nauczając, przekazywał owoce swej kontemplacji (Wójtowicz, 2015).

10 „Sprawiedliwość zaś nie może istnieć, jeśli nie ma sprawiedliwych ludzi. I znowu: korzenie, z których czerpiemy siłę do bycia sprawiedliwymi, sięgają głębiej niż nasze myśli i czyny, do prawa i prawdy, które w stworzeniu zaszczepił sam Stwórca. [...] Im więcej będzie sprawiedliwych, tym bardziej żywotne i pomyślne będą więzi spajające daną wspólnotę. [...] Odwołanie do Boga w konstytucji przypomina nam, że prawo nie może się rozwijać i być sprawiedliwe, jeśli nie ma swojej miary pouczającej nas o tym, co jest sprawiedliwe. Miary, która przewyższa każdego z nas, która każdego potrafi zmierzyć i przed którą wszyscy jesteśmy równi" (Ratzinger, 2016, s. 40-41, 81).

${ }^{11}$ Zwrócenie uwagi na rok wydania jest ważne, ponieważ po ukazaniu się encykliki Evangelium vitae (1995) do tego sformułowania został zamieszczony w następnych wydaniach „tonujący”. 


\subsection{OKRES OD ROZPOCZĘCIA PONTYFIKATU JANA PAWŁA II (16.10.1978 R.)}

Jan Paweł II (pontyfikat w latach 1978-2005) niejednokrotnie apelował o zniesienie kary śmierci. Zagadnienie to poruszał m.in. w encyklice Evangelium vitae (25 III 1995 r. - dalej cyt. EV) (Jan Paweł II, 1995) nawiązując do Katechizmu Kościoła Katolickiego i przytaczając przykład samoobrony:

Zdarza się niekiedy, że konieczność odebrania napastnikowi szkodzenia prowadzi czasem do pozbawienia go życia. W takim przypadku spowodowanie śmierci należy przypisać samemu przeciwnikowi, który naraził się na nią swoim działaniem, także w sytuacji, kiedy nie ponosi moralnej odpowiedzialności ze względu na brak posługiwania się rozumem (EV 55).

Jest to głos konserwatywno-liberalny (,za”, nie wykluczający „przeciw”), uzasadniany perspektywą zastosowania kary zastępczej wielu lat więzienia lub dożywocia, co umożliwiają zaistniałe - wskutek ciągłego rozwoju cywilizacyjnego - możliwości i warunki. Priorytetowym argumentem jest

godność człowieka ${ }^{12}$, a tym samym - w ostatecznej analizie - zamysł Boga względem człowieka [...], [nie powinno się więc - K.P.] sięgać do najwyższego wymiaru, czyli do odebrania życia przestępcy, poza przypadkami absolutnej konieczności, to znaczy gdy nie ma innych sposobów obrony społeczeństwa (EV 56).

Jednocześnie papież Jan Paweł II wyraźnie łagodzi to zastrzeżenie, wyrażając stanowisko, iż w obecnej sytuacji, „dzięki coraz lepszej organizacji instytucji penitencjarnych, takie przypadki są bardzo rzadkie, a być może już nie zdarzają się wcale" (EV 56).

Podsumowując; głos sprzeciwu nie jest bezwarunkowy. Występuje możliwość niestosowania kary śmieci ze względu „na godność człowieka”, przekazywaną osobie ludzkiej zgodnie ,z zamysłem Boga”.

\footnotetext{
${ }^{12}$ Godność osoby ludzkiej (łac. „dignitas” - godność, wartość osobista, zasługa; „dignatio” - godność, dostojeństwo) - pojęcie odzwierciedlające w swoim podstawowym znaczeniu powszechne przekonanie o szczególnym statusie istot ludzkich w stosunku do wszystkich innych bytów stworzonych. Fundamentalna godność osoby ludzkiej jest wrodzona, właściwa wszystkim ludziom i niezbywalna (Machinek, 2014).
} 


\subsection{TEOLOGICZNE UZASADNIENIE SPRZECIWU WOBEC KARY ŚMIERCI}

Postawa „przeciw” karze śmierci znajduje swoje teologiczne uzasadnienie w „zamyśle Boga” w odniesieniu do człowieka, ukazanym na początku Jego zbawczego działania w opowiadaniu biblijnym o Kainie i Ablu (Rdz 4, 1-16). Historię tę należy „czasowo” przenieść w jego powstaniu w czasy późniejsze aniżeli jego kontekst tzw. prehistorii biblijnej (Rdz 1-11) ${ }^{13}$. Stare Przymierze zdecydowanie nakazywało „nie będziesz zabijał” (Wj 20, 13), nie interpretując tego zakazu w sposób absolutny. Oprócz tego termin hebrajski lo'tircah - powszechnie tłumaczony „nie zabijał” - należałoby przetłumaczyć: „nie morduj” (Zorell, 1960, s. 787).

Bez wątpienia cała Biblia wypełniona jest ,szczękiem oręża i krzykiem zabijanych”. Zabijał Dawid, wybraniec Boży, wspaniały poeta, wysyłający męża swej kochanki na front z krótką instrukcją „«Postawcie Uriasza tam, gdzie walka będzie najbardziej zażarta, potem odstąpicie go, aby został ugodzony i zginał»” (2 Sm 11, 15) (Frossard, 1995, s. 40). W ogóle cała historia „wojen Jahwe" sygnalizuje Jego przyłączenie się, nie bezpośrednio, do walki, polecając jednak zabijać tych, którzy wyjdą poza nakaz przymierza oraz zamiary Boże (por. Wj 21, 12-17; 21, 23-24; 22, 18; 31, 14; Kpł 20, 1-5.9-17.27; Pwt 21, 18-21.22-27). Drastyczny przykład to przebicie włócznią Izraelity, który przeżywał stosunek „sakralny” z Moabitką. Mąż, który przebił obydwoje, a „kobietę przez jej łono", został pochwalony przez Jahwe. Przez Mojżesza rozkazał On: „Jak z wrogiem obchodź się z Moabitami i wyniszcz ich” (Lb 25, 1-18). Równocześnie wszelkie przejawy zła, tragedii, cierpienia Stary Testament wiąże z Bogiem jako ich bezpośrednim sprawcą. „Ja zabijam i Ja sam ożywiam, Ja ranię i Ja sam uzdrawiam, że nikt z mojej ręki nie uwalnia" (Pwt 32, 39). „To Pan daje śmierć i życie, wtrąca do Szeolu i zeń wyprowadza” (1 Sm 2,6) (Czajkowski, 1998, s. 20-24).

Odwoływanie się do Opatrzności Bożej dawało „usprawiedliwienie” w odbieraniu życia, kiedy w sposób wykluczający przypadkowość naruszało ono życie bliźniego, świadczące o „nieuzasadnionym” zabójstwie. Dowodzi tego termin użyty w Dekalogu, a jest nim czasownik hebrajski racah („rzezać”,

\footnotetext{
${ }^{13}$ Nie jest to „prehistoria” analogiczna do prehistorii świeckiej, liczonej „przed” lub „po” narodzeniu Chrystusa względnie „przed naszą erą” lub „naszej ery”, bez podania wydarzenia historycznego lub historycznej postaci, co wydaje się nielogiczne z powodu zastosowania zaimka „nasza”, opierającego się chronologicznie na „Chrystusie”. Zmiana tej nomenklatury jest podyktowana wykluczeniem Chrystusa z historii, co - wobec powyższego wytłumaczenia - jest połowiczne, nawet wobec faktu, że Chrystus przyszedł na świat w 6/7 r. ,przed Chrystusem”, co zostało odkryte dopiero w XIX w. (Ziółkowski, 2006, s. 62-68).
} 
w znaczeniu „mordować”). W Biblii termin ten nigdy nie pozostał użyty w stosunku do zwierząt ani do zabijania na polu walki - w czasie wojny, ani też do kary śmierci wymierzonej przez Boga, ani przez legalny trybunał ludzki. Wyraz racah zawsze oznacza samowolne - wywodzące się z pobudek czysto osobistych, częstokroć zaplanowane i będące przejawem egoizmu lub zemsty - uśmiercenie drugiego człowieka, co w polskim języku optymalnie oddaje czasownik „mordować” (Muszyński, 1993, s. 116). Aby uniknąć morderstw w duchu wendety, Bóg zezwolił Izraelowi na powołanie specjalnej instytucji penitencjarnej, tzw. miasta ucieczki, w którym mógł schronić się zabójca przed wyrokiem sądu (Lb 35, 6-32; Joz 21, 13) ${ }^{14}$.

Za morderstwo wymierzano w Izraelu karę śmierci, a argumentowano ją w następujący sposób: „Jeżeli kto przeleje krew ludzką, przez ludzi ma być przelana krew jego, bo człowiek został stworzony na obraz Boga" (Rdz 9, 6). Jest to sentencja występująca w opisach ,prehistorycznych”, interpretująca stosowanie kary śmierci, która była stosowana wprawdzie dalej, czyli po schyłku monarchii w XIII-VI w. przed Chr., będącej w historii zbawienia koniecznym etapem w realizacji przez Boga zamiaru zbawczego ${ }^{15}$. Uzasadnienie niestosowania kary śmierci znajduje się na początku objawienia biblijnego, w nieco innym wymiarze rozumienia, podstawowym i zasadniczym.

Jan Paweł II nawiązuje do zasady, opisanej w przytoczonym już opowiadaniu o Kainie i Ablu (Rdz 4, 1-16), w rozdziale I: „«Krew brata twego głośno woła ku mnie z ziemi». Aktualne zagrożenia życia ludzkiego" encykliki Evangelium vitae (p. 7-10), w którym przytacza prawdę zdefiniowaną w pierwszej połowie I w. przed Chr. Taki czas powstania podają bibliści i historycy Księgi Mądrości w języku greckim - słowami charakteryzującymi rozwój leksykalny i gramatyczny mowy ludzkiej:

${ }^{14}$ Miasta ucieczki (hebr: עיר מקלט) - sześć biblijnych miast lewickich, w którym nieumyślny zabójca mógł znaleźć schronienie przed wendetą: Beser, Ramot, Golan, Hebron, Sychem, Kedesz. Prawo nieumyślnego zabójcy do szukania schronienia wspomniane zostało w Księdze Wyjścia (Wj 21, 13). Miejscem tym był początkowo ołtarz ofiarny, o czym świadczy następny wers. Prawo to różniło się od praw innych ludów starożytnych, gdyż w innych tradycjach każdy, a nie tylko zabójca, mógł skorzystać ze schronienia w świątyni. Miasta ucieczki zostały wskazane przez Mojżesza, gdy Naród Wybrany znalazł się na pograniczu kananejskim po wyjściu z Egiptu. Według Księgi Liczb (Lb 35, 6, 13-14), Księgi Powtórzonego Prawa (Pwt 4, 43; 19, 2, 7-9) i Księgi Jozuego (Joz 20, 7-8) były to trzy miasta kananejskie (Hebron, Sychem i Kedesz) oraz trzy zajordańskie (Beser, Ramot i Golan).

${ }^{15}$ W XIII w. miało miejsce zawarcie przymierza, które zostało zerwane przez Izraela w VII w. przed Chr. Po powrocie z wygnania Bóg odnowił przymierze, ale okres Jego działania głównie przez wydarzenia polityczne skończył się. Hagiograf Listu do Hebrajczyków tak ujmuje ten okres: „Wielokrotnie i na różne sposoby przemawiał niegdyś Bóg do ojców przez proroków, a w tych ostatecznych dniach przemówił do nas przez Syna. Jego to ustanowił dziedzicem wszystkich rzeczy, przez Niego też stworzył wszechświat” (Hbr 1, 1-2). 
Bo śmierci Bóg nie uczynił i nie cieszy się ze zguby żyjących. Stworzył bowiem wszystko po to, aby było [...] Bo dla nieśmiertelności Bóg stworzył człowieka [wyróżn. K. P.] - uczynił go obrazem swej własnej wieczności. A śmierć weszła na świat [wyróżn. K. P.] przez zawiść diabła i doświadczają jej ci, którzy do niego należą (Mdr 1, 13; 2, 23-24).

Opisaną sytuację spowodowali pierwsi rodzice, Adam i Ewa, lekceważąc Boga i przystając do węża, czyli do diabła:

A wąż był bardziej przebiegły niż wszystkie zwierzęta lądowe, które Pan Bóg stworzył. On to rzekł do niewiasty: „Czy rzeczywiście Bóg powiedział: Nie jedzcie owoców ze wszystkich drzew tego ogrodu?" (Rdz 3, 1).

Nie przypadkiem hagiograf opowiadania o upadku pierwszych ludzi jako pierwszy grzech przedstawił bratobójstwo Kaina ( $\mathrm{Rdz} 4,1-16)$, zrealizowane wskutek zawiści diabła. Śmierć ,wchodzi na świat przemocą poprzez zabójstwo Abla, który ginie z ręki swego brata Kaina: «gdy byli na polu, Kain rzucił się na swego brata Abla i zabił go»" (Rdz 4, 8) (EV 7).

Jan Paweł II komentuje to w sposób następujący:

Podobnie jak w pierwszym bratobójstwie, tak i w każdym zabójstwie człowieka zostaje podeptana więź pokrewieństwa „duchowego”, która łączy ludzi w jedną wielką rodzinę, jako że wszyscy mają udział w tym samym podstawowym dobru. W równej godności osobowej. [...] U korzeni wszelkiej przemocy skierowanej przeciwko bliźniemu leży ustępstwo na rzecz „logiki” Złego, to znaczy tego, który „od początku był zabójcą” (por. J 8, 44) (EV 8).

Taka bowiem jest wola Boża, którą objawiono nam od początku, abyśmy się wzajemnie miłowali. Nie tak, jak Kain, który pochodził od Złego i zabił swego brata [...] $(1 \mathrm{~J} \mathrm{3}, 11-12)^{16}$.

Opisywane zabójstwo było popełnione z premedytacją, nie liczącą się z nikim i z niczym, nawet z Bogiem, o czym dowodzi lekceważąca odpowiedź Kaina: „[...] «Nie wiem. Czyż jestem stróżem brata mego?»” (Rdz 4, 9). Kain, nawet po wyroku, utrzymuje się w swym uporze i gani Boga, będąc pewny, że postępuje On podobnie jak człowiek, narażając go na śmierć z tytułu ,prawa

${ }^{16}$ Diabeł jest wymieniony w Ojcze nasz w zwrocie: „[...] ale nas zbaw ode złego”; „Zło, o którym mówi ta prośba, nie jest jakąś abstrakcją, lecz oznacza osobę, Szatana, Złego, anioła, który sprzeciwił się Bogu. „Diabeł” („dia-bolos”) jest tym, który „przeciwstawia się” zamysłowi Boga i Jego „dziełu zbawienia” wypełnionemu w Chrystusie» (Katechizm, 2012, 2851). 
pomsty", czyli zamordowania przez braci, natomiast hagiograf głosi inną prawdę, wkładając w usta Boga słowa: ,[...] «O, nie! Ktokolwiek by zabił Kaina, siedmiokrotną pomstę poniesie!» Dał też Pan znamię Kainowi, aby go nie zabił, ktokolwiek go spotka. Po czym Kain odszedł od Pana i zamieszkał w kraju Nod, na wschód od Edenu (Rdz 4, 15-16)" (EV 7).

W tym wypadku Bóg stanął w obronie prawdopodobnego zagrożonego życia Kaina. Z opisu tekstu Jan Paweł II wyciąga wniosek, iż aprobowanie prawa do życia, którego „dysponentem” (Panem) jest tylko Bóg, odnosi się nawet do tych ludzi, którzy złamali prawo Boże w sposób najwyższy. Papież przypomniał, że Pan Bóg, karząc brata zabójcę, jednocześnie chronił go przed społeczeństwem, które chciałoby pozbawić życia również Kaina. Jan Paweł II wypowiada znamienne słowa: „Nawet zabójca nie traci swej osobowej godności i Bóg sam czyni się jej gwarantem [wyróżn. K. P.]" (EV 9) (Nitecki, 2003, s. 222). I w innym miejscu pisze:

Właśnie tutaj objawia się paradoksalna tajemnica miłosiernej sprawiedliwości Boga, o której pisze św. Ambroży: „Skoro zostało popełnione bratobójstwo, czyli największa ze zbrodni, w momencie gdy wszedł na świat grzech, natychmiast też musiało zostać ustanowione prawo Bożego miłosierdzia; gdyby bowiem kara spadła bezpośrednio na winnego, ludzie nie okazywaliby umiaru ani łagodności w karaniu, ale natychmiast wymierzaliby karę winowajcom. [...] Bóg odrzucił Kaina sprzed swojego oblicza, a gdy wyrzekli się go także rodzice, nakazał mu żyć jakby na wygnaniu, w osamotnieniu, ponieważ zwierzęca dzikość wyparła zeń ludzką łagodność. Jednakże Bóg nie zamierza ukarać zabójcy zabójstwem, gdyż chce nawrócenia grzesznika bardziej niż jego śmierci” (EV 9).

Wsparcie się na objawieniu biblijnym jest podstawą podejścia teologicznego do kary śmierci. Podejście to jest oparte na przeświadczeniu o świętości życia każdego czlowieka, z czego wynika zasada jego nienaruszalności. „Życie człowieka pochodzi od Boga, jest Jego darem, Jego obrazem i odbiciem, udziałem w Jego ożywczym tchnieniu. Dlatego Bóg jest jedynym Panem tego życia, człowiek nie może nim rozporządzać [...]" (EV 39). Prawda ta w nowym świetle ujawnia się z chwilą Wcielenia, powodowanego miłością Boga do człowieka, i brzmi następująco: „Tak bowiem Bóg umiłował świat, ze Syna swego Jednorodzonego dał, aby każdy, kto w Niego wierzy, nie zginął, ale miał życie wieczne" (J 3, 16). Jest to poświęcenie Syna, Jezusa Chrystusa, który zmarł w wyniku wyroku kary śmierci, orzeczonej przez Trybunał Rzymski, kary najboleśniejszej i najhaniebniejszej: przez przybicie skazanego gwoźdźmi do krzyża (Kucharska, 2015, s. 109-123). Dlatego Jezus domaga się od swoich uczniów sprawiedliwości 
doskonalszej aniżeli sprawiedliwość uczonych w Piśmie i faryzeuszy, także w dziedzinie poszanowania życia, słowami: „Słyszeliście, że powiedziano przodkom: Nie zabijaj!; a kto by się dopuścił zabójstwa, podlega sadowi” (Mt 5, 21). Żaden człowiek nie powinien być obcy dla potrzebujących, powinien być bliźnim i poczuwać się do odpowiedzialności za ich życie, w taki sposób, że nawet wróg przestaje być wrogiem i ma obowiązek go kochać (por. Mt 5, 38-48; Łk 6, 27-35).

Nauczanie Jana Pawła II na temat kary śmierci miało radykalny wpływ na oficjalną naukę Kościoła, którego odzwierciedleniem są zapisy w najnowszym wydaniu Katechizmu Kościoła Katolickiego. We wcześniejszej wersji z 1992 r. problematyka ta została ujęta w duchu konserwatywnego sposobu rozumienia tego problemu, w kontekście uprawnionej obrony własnej i ochrony wspólnego, społecznego dobra. Po ukazaniu się jednak encykliki Evangelium vitae kwestia kary śmierci została znacznie zliberalizowana. Jakkolwiek nadal podkreśla się w Katechizmie (postawa „za”), że: „[...] tradycyjne nauczanie Kościoła nie wyklucza zastosowania kary śmierci, jeśli jest ona jedynym dostępnym sposobem skutecznej ochrony ludzkiego życia przed niesprawiedliwym napastnikiem" (KKK 2267; wyd. przed 1995 r.), opowiadając się jednocześnie za bezkrwawymi środkami obrony (postawa „przeciw”), które odpowiadałyby godności osoby ludzkiej. Do tradycyjnego sformułowania sprzed 1995 r. został dodany tekst ograniczający akceptację dla kary śmierci. Oto dodany fragment:

[...] Biorąc pod uwagę możliwości, jakimi dysponuje państwo, aby skutecznie ukarać zbrodnię i unieszkodliwić tego, kto ją popełnił, nie odbierając mu ostatecznie możliwości skruchy, przypadki absolutnej konieczności usunięcia winowajcy są bardzo rzadkie, a być może już nie zdarzają się wcale (KKK 2267, wyd. 2012).

Ostatecznym argumentem „przeciw” karze śmierci jest godność człowieka i umożliwienie mu skruchy za popełniony czyn, czyli powrót do bycia „dzieckiem Bożym”. „Wszystkim tym jednak, którzy Je [Słowo Boże - K.P.] przyjęli, dało moc, aby się stali dziećmi Bożymi, tym, którzy wierzą w imię Jego" (J 1, 12). Kara śmierci odbiera się człowiekowi prawo do skruchy, przynajmniej częściowej naprawy krzywdy, a przede wszystkim możliwość poprawy swojego życia.

Gdy Jezus odwiedził Nikodema, przywódcę religijnego, dostojnika żydowskiego, nie od razu zapewnił go o niebie. Chrystus rzekł: „,...] «Zaprawdę, zaprawdę powiadam ci, jeśli się ktoś nie narodzi powtórnie, nie może ujrzeć Królestwa Bożego»" (J 3, 3).

Należy zgodzić się z postawioną na wstępie tezą, iż papież Jan Paweł II istotnie przyczynił się do zmiany postawy Kościoła katolickiego w kwestii stosowania kary śmierci, wpływając jednocześnie na zmianę stosunku wielu 
wyznawców wiary katolickiej do tej kwestii. Dzięki Jego nauce wierni dostrzegli bezsens tejże kary, a sam Papież uznawał ją za część „kultury śmierci” (EV 87). Jan Paweł II stał się świadkiem nadziei, zagorzałym obrońcą życia i tym samym przeciwnikiem kary śmierci.

Prawo odwetu w Starym Testamencie stoi w niezgodzie z duchem Nowego Testamentu, który stał się szczególną „księgą miłości”. Wcześniejsza zasada ius talionis (prawo odwetu) zastąpiona została zasadą miłosierdzia i przebaczenia (Wejman, 2016, s. 185-200). Prawo pozwalające na zabijanie zawsze pozostanie bezprawiem według moralności i etyki religii chrześcijańskiej.

Stosunek do kary śmierci Kościoła katolickiego ma cechy personalistyczne ${ }^{17}$, dopuszczające nawet dla zbrodniarza możliwość resocjalizacji, albowiem gdy każda jednostka traktowana jest jako twórca (Konopczyński, 2010) samej siebie, istnieje szansa, że będzie chciała się zmienic ${ }^{18}$. Wtenczas to nie kara wymusza zmianę, to czlowiek musi akceptować karę, która wpływa na jego wewnętrzne decyzje dokonywania egzystencjalnej przemiany (Bałandynowicz, 2011, s. 235). Podstawą takiego zaangażowania jest przekonanie o prawdziwym sensie życia i wartości własnej „siebie”.

Tę właśnie rzeczywistość Jan Paweł II ujął w zdaniu, które stało się sentencją zarówno w kręgach ludzi wierzących, jak i niewierzących. Są to słowa skierowane do więźniów 7 VI 1991 r. podczas ich nawiedzenia w Płocku: „Jesteście skazani, to prawda, ale nie potępieni. Każdy z was może zostać przy pomocy Bożej łaski - świętym. Dlatego jestem tu dziś z wami, a poprzez was z tymi wszystkimi, którzy dzielą wasz los" (Jan Paweł II, 1991, s. 237; zob. też Pierzchała, 2015).

Stanowisko Ojca Świętego, jak wykazują badania, wypływa nie tylko stąd, iż nie ma wyraźnego związku między orzekaniem a wykonywaniem kary śmierci czy też wzrostem bądź zmniejszeniem się przestępczości, lecz przede wszystkim stąd, że - opierając się na Objawieniu Bożym - ochrona życia każdego człowieka obowiązuje zawsze, gdyż jest prawem uniwersalnym, od którego nie mogą istnieć żadne wyjątki.

Na zakończenie zacytuję słowa ks. prof. Manfreda Uglorza (2012), pozostawiając je bez komentarza: „Nawoływanie do przywrócenia kary śmierci za

\footnotetext{
${ }^{17}$ Personalizm - 1. filoz:: „,koncepcje filozoficzne przyjmujące za punkt wyjścia problematykę osobowości ludzkiej pojmowanej jako byt natury duchowej, obdarzony świadomością i wolą, twórczy, wolny i odpowiedzialny moralnie; od XIX w. samodzielny kierunek w filozofii"; 2. psych.: „kierunek psychologiczny, według którego różne funkcje psychiczne są ściśle ze sobą związane i nie można rozpatrywać ich w oderwaniu od całokształtu osobowości” (Bańko, 2014).

${ }^{18}$ Wszechstronne przedstawienie tego problemu znajduje się w studium naukowym, uwzględniającym osiągnięcia współczesnej psychologii penitencjarnej i nauczania Magisterium Kościoła (Pierzchała, 2016; Pierzchała, 2017a, s. 17-37).
} 
najbardziej okrutne zbrodnie jest nie tylko problemem prawnym, ale przede wszystkim etycznym".

\section{PODSUMOWANIE}

Akulturacja jest procesem długofalowym, w wyniku którego wytwarzane są najróżniejsze strategie przystosowawcze, będące następstwem rozciągniętej w czasie koegzystencji różnych grup.

Zdolność wpływania na zachowanie państwa w dziedzinie praw człowieka tradycyjnie jest rozumiana poprzez ramy składające się z dwóch metod: przymusu i perswazji. Luka pozostawiona przez wymienione metody/teorie wypełnia się poprzez akulturację. Akulturacja natomiast jest procesem, który zachodzi bardziej niepostrzeżenie aniżeli przymus i perswazja, wyjaśniając podobieństwa między problemami, poprzez ocenę wewnętrznych i zewnętrznych, poznawczych presji społecznych, które wiążą się z określoną grupą środowiska społecznego.

Akulturacja w pełniejszy sposób wyjaśnia podobieństwa między Stanami Zjednoczonymi a Europą w opracowywaniu doktryn dotyczących kary śmierci, ilustrując to, w jaki sposób członkostwo Stanów Zjednoczonych w grupie rozwiniętych zachodnich demokracji, które szanują prawa człowieka, grupie, która obejmuje również Europę, powoduje doświadczanie nacisków poznawczych i społecznych, tak aby utrzymać swoją tożsamość przywódcy praw człowieka, a tym samym ograniczyć (zlikwidować) stosowanie kary śmierci (Patterson, 2006, s. 1246).

Czy głos „przeciw” karze śmierci papieża Jana Pawła II został podyktowany prawodawstwem europejskim? Czy zadziałał tutaj akulturalizm europejski? Jeżeli Jan Paweł II nie miał wpływu na ten proces, to z pewnością się przyczynił do zmiany stosunku katolików do kwestii stosowania kary śmierci. Papież Jan Paweł II był człowiekiem, który przyswajał na grunt kościelny postępowe idee życia publicznego i tego nie ukrywał. Był bowiem jednym z najlepszych znawców problematyki światowej. Wiele pielgrzymował, nauczał i wyciągał wnioski. Mało kto tak jak On rozumiał nowoczesność, potrafiąc jednocześnie zachowywać tradycyjne myślenie i łączyć je z nowymi osiągnięciami ducha ludzkiego. Piotr Nitecki (2006) podkreśla, że

Jan Paweł II, podejmując to zagadnienie, sięgał do najbardziej zasadniczej, antropologicznej i teologicznej argumentacji za życiem w ogóle, przeciwko zadawaniu śmierci drugiemu człowiekowi, a więc także przeciwko karze śmierci. Nie brał 
więc udziału w dyskusji między zwolennikami a przeciwnikami kary śmierci, opowiadając się po którejś ze stron toczącego się sporu, lecz mocą swego autorytetu apostolskiego sięgał do samych podstaw orędzia chrześcijańskiego, poszukując w nim odpowiedzi na pytanie o zasadność orzekania i wykonywania tej kary.

Katolicka etyka teologiczna mówi wyraźnie: karze śmierci „nie”. Według niej nie może być stosowana kara śmierci pod żadnym pozorem i w żadnym wypadku. Papież Franciszek odniósł się do tematu kary śmierci 11.10.2017 r. w czasie audiencji w Watykanie dla uczestników spotkania zorganizowanego przez Radę ds. Krzewienia Nowej Ewangelizacji z okazji 25. rocznicy ukazania się Katechizmu Kościoła Katolickiego:

Zauważył [...], że wiele uwagi KKK poświęca karze śmierci, wykazując jej sprzeczność z nauczaniem Bożym. Franciszek po raz kolejny zaapelował o jej zniesienie, mówiąc, że nie można się odwoływać jedynie do nauczania z przeszłości, nie uwzględniając wypowiedzi późniejszych papieży, ale też rosnącej samoświadomości ludu Bożego. Odrzucenie tego rodzaju kary wiąże się z coraz powszechniejszym przekonaniem, iż jest ona nie do pogodzenia z godnością ludzką, którą - jak podkreślił - „upokarza ona i w pewnym sensie prześladuje”. I z tego powodu jest sprzeczna z Ewangelią, głoszącą świętość życia ludzkiego w oczach Stwórcy, który jest jedynym i ostatecznym Sędzią - zaznaczył papież (Gość.pl, 2017).

Na początku 2018 r. papież Franciszek w jednej z wypowiedzi jednoznacznie podtrzymał swoje wcześniejsze stanowisko dotyczące kary śmierci.

\section{BIBLIOGRAFIA}

Ambrogio di Milano [Ambroży z Mediolanu], De Cain et Abel, II, 10, 38. CSEL 32.

Ancel, M.M. (1962). European Comm'n on Crime Problems, the Death Penalty in European Countries, 8.

BaŁandynowicz, A. (2011). Probacja. Resocjalizacja z udziałem społeczeństwa. Warszawa: Wydawnictwo Wolters Kluwer Polska.

Bańko, M. (red.) (2014). Wielki słownik wyrazów obcych PWN. Warszawa: Wydawnictwo Naukowe PWN.

Beccaria, C. (2014). O przestępstwach i karach. (I wyd. 1764). Łódź: Wydawnictwo Uniwersytetu Łódzkiego.

Boski, P. (2009). Kulturowe ramy zachowań społecznych. Podręcznik psychologii międzykulturowej. Warszawa: Wydawnictwo Naukowe PWN, Academica. Wydawnictwo SWPS. 
Cieślak, M. (1985). Przestępstwa przeciwko zdrowiu i życiu. W: I. Andrejew, L. Kubicki, J. WaszczyŃski (red.), System prawa karnego. T. 4: O przestępstwach w szczególności (cz. 1). Wrocław-Warszawa-Kraków-Gdańsk-Łódź: Zakład Narodowy im. Ossolińskich, Polska Akademia Nauk.

Czajkowski, M. (1988). Biblia dziś odczytana. Warszawa: Wydawnictwo NOVUM.

Dugard, J., Wyngaert, Chr. Van den (1998). Reconciling Extradition with Human Rights. American Journal of International Law, 92(2), 187-212.

FEC, I. (2016). Kościół i państwo - wspólna troska. Niedziela Rzeszowska, 10.

Frossard, A. (1995). Stuchaj, Izraelu! Warszawa: Wydawnictwo Palabra.

Glombik, K., Nitecki, P. (2014). Kara śmierci. W: A. Zwoliński, J. Nagórny, K. Jeżyna, E. SAKowICz (red.), Wielka Encyklopedia Nauczania Jana Pawta II. Radom: Polskie Wydawnictwo Encyklopedyczne Polwen.

Goodman, R., Jinks, D. (2004). How to Influence States: Socialization and International Human Rights Law [Jak wpływać na państwa: socjalizacja i międzynarodowe prawo dotyczące praw człowieka]. Duke Law Journal, 54(3), 621-703.

Hood, R. (1999). Introduction [Wprowadzenie]. W: T. Kleinsorge, B. Zatlokal (red.), The Death Penalty: Abolition in Europe [Kara śmierci: abolicja w Europie]. Strasbourg: Council of Europe Publishing.

JAKubowski, G. (2002). Sadownictwo powszechne w Polsce w latach 1944-1950. Warszawa: Instytut Pamięci Narodowej.

JAN PAWEe II (1991). „Byłem w więzieniu, a przyszliście do mnie”. Spotkanie z więźniami. Płock, 7 czerwca 1991. W: Ducha nie gaście. Jan Pawet II w Polsce. 1-9 czerwca 1991 r. IV pielgrzymka do Polski. Paryż: Editions Dembiński. International Polish Book Club.

JAN PAWEŁ II (1995). Encyklika „Evangelium vitae” o wartości i nienaruszalności życia ludzkiego. Rzym.

Kallas, M. (2001). Historia ustroju Polski X-XX w. Warszawa: Wydawnictwo Naukowe PWN.

Katechizm Kościoła Katolickiego (2012). Wyd. II poprawione. Poznań: Pallottinum.

Konopczyński, M. (2010). Metody twórczej resocjalizacji. Warszawa: Pedagogium WSNS, Wydawnictwo Naukowe PWN.

KucharsKa, E. (2015). Męka i śmierć na krzyżu w aspekcie medycznym. Na kanwie rozważań o Jezusie Chrystusie Synu Człowieczym, red. J. KrĘCidŁo. Kraków: Wydawnictwo La Salette. „Studia Salettensia”, t. 6.

Machinek, M. (2014). Godność osoby ludzkiej. W: A. Zwoliński, J. Nagórny, K. Jeżyna, E. SAKowICZ (red.), Wielka encyklopedia nauczania Jana Pawła II. Radom: Polskie Wydawnictwo Encyklopedyczne Polwen.

Michalska, A. (1984). Prawo do życia w traktatach międzynarodowych. Ruch Prawniczy, Ekonomiczny i Socjologiczny, 46(3), 73-94.

MuszyńsKi, H.J. (1993). Dekalog. Gniezno: Wydawnictwo Gaudentinum.

Nitecki, P. (2003). Kara śmierci. W: A. Zwoliński (red.), Encyklopedia nauczania społecznego Jana Pawła II. Radom: Polskie Wydawnictwo Encyklopedyczne Polwen.

Nitecki, P. (2006). Jan Paweł II o karze śmierci. Nowe Życie, 9.

Nowicka, E. (1998). Akulturacja. W: W. KwaśnIEwICZ (red.), Encyklopedia socjologii (t. 1). Warszawa: Wydawnictwo Oficyna Naukowa. 
PierzchaŁa, K. (2008). Kara śmierci w aspekcie prawnym i etyczno-moralnym. W: K. PierzChaŁa, Cz. CeKiera (red.), Zwalczanie patologii społecznych w systemie penitencjarnym Polski i USA (s. 29-31). Toruń: Wydawnictwo Adam Marszałek.

PierzchaŁa, K. (2015). Skazani ale nie potępieni. Wyd. II rozszerzone. Toruń: Wydawnictwo Adam Marszałek.

PierzchaŁa, K. (2016). Destygmatyzacja przestępców w świetle Magisterium Kościoła oraz pogladów na resocjalizację. Kraków: Oficyna Wydawnicza „Impuls”.

PierzchąA, K. (2017a). Pedagogical and Theological Reflections on the De-Stigmatization Process [Refleksje pedagogiczno-teologiczne nad procesem destygmatyzacji]. Resocjalizacja Polska (Polish Journal of Social Rehabilitation), 13, 17-37.

PierzchaŁa, K. (2017b). Wina - prawo - kara. Prawne i psychopedagogiczne aspekty resocjalizacji penitencjarnej [Fault - Law - Penalty. Legal and Psycho and Pedagogical Aspects of Penitentiary Rehabilitation]. Probacja, 3, 91-117.

Pilch, T. (red.) (2003). Encyklopedia pedagogiczna XIX wieku (t. 1). Warszawa: Wydawnictwo Akademickie ,Żak”.

Ratzinger, J. (2016). Głód Boga. Kazania z Pentling (tł. P. Kaźmierczak). Kraków: Wydawnictwo WAM.

Stachowski, Z. (2004a). Akulturacja. W: M. Libiszowska-ŻóŁtkowska, J. Mariański (red.), Leksykon socjologii religii. Zjawiska - badania - teorie. Warszawa: Wydawnictwo Księży Werbistów VERBINUM.

Stachowski, Z. (2004b). Inkulturacja. W: M. Libiszowska-ŻóŁtkowsKa, J. Mariański (red.), Leksykon socjologii religii. Zjawiska - badania - teorie. Warszawa: Wydawnictwo Księży Werbistów VERBINUM.

Thomas, W.I., Znaniecki, F. (1976). The Polish Peasant in Europe and America. Boston 19181920. Wyd. pol. Chłop polski w Europie i Ameryce (t. 1-5). Warszawa: Ludowa Spółdzielnia Wydawnicza.

Utrat-Milecki, J. (2004). Kara. W: M. Libiszowska-ŻóŁtkowsKa, J. Mariański (red.), Leksykon socjologii religii. Zjawiska - badania - teorie. Warszawa: Wydawnictwo Księży Werbistów VERBINUM.

Wejman, H. (2016). Miłosierdzie Boga a duch skruchy i przebaczenia w życiu człowieka. Colloquia Theologica Ottoniana, 2, 185-200.

Wielka encyklopedia nauczania Jana Pawła II (2014). Wydanie zebrane i poprawione. Radom: Polskie Wydawnictwo Encyklopedyczne Polwen.

Zı́́ŁKowski, Z. (2006). Najtrudniejsze stronice Nowego Testamentu. Warszawa: Oficyna Wydawnicza ADAM.

ZnANIECKI, F. (2001). Ludzie teraźniejsi a cywilizacja przyszłości. Wyd. I - 1934. Warszawa: Wydawnictwo Naukowe PWN.

Zorell, F. (1960). Lexicon hebraicum et aramaicum Veteris Testamenti. Roma.

\section{AKTY PRAWNE}

Dekret z dnia 22 stycznia 1946 r. o Najwyższym Trybunale Narodowym (Dz. U. 1946, nr 5, poz. 45).

Drugi Protokół Fakultatywny do Międzynarodowego Paktu Praw Obywatelskich i Politycznych w sprawie zniesienia kary śmierci, przyjęty w Nowym Jorku dnia 15 grudnia 1989 r., G.A. 
Res. 44/128, U.N. GAOR, 44th Sess., Supp. No. 49, at 206, U.N. Doc. A/44/49 (Dz. U. z 2014, poz. 891).

International Covenant on Civil and Political Rights z 16 grudnia 1966, weszła w życie 23 marca 1976. S. EXEC. DOC. E, 95-2, 999 U.N.T.S. 171.

Karta Praw Podstawowych Unii Europejskiej z 7 grudnia 2000 r., 2012/C 326/02.

Konkordat między Stolicą Apostolską i Rzeczpospolitą Polską, podpisany w Warszawie 28 lipca 1993 r. (Dz. U. 1998, nr 51, poz. 318).

Konstytucja Rzeczypospolitej Polskiej z dnia 2 kwietnia 1997 r. (Dz. U. z 1997 r., nr 78, poz. 483 z późn. zm.).

Konwencja o ochronie praw człowieka i podstawowych wolności, sporządzona w Rzymie dnia 4 listopada 1950 r., zmieniona następnie Protokołami nr 3, 5 i 8 oraz uzupełniona Protokołem nr 2 (Dz. U. 1993, nr 61, poz. 284).

Konwencja o prawach dziecka, przyjęta przez Zgromadzenie Ogólne Narodów Zjednoczonych dnia 20 listopada 1989 r., G.A. Res. 44/25, U.N. GAOR Supp. No. 48, at 166, U.N. Doc. A/Res/ 44/99 (Dz. U. 1991, nr 120, poz. 526).

Protokół nr 13 do Konwencji o ochronie praw człowieka i podstawowych wolności dotyczący zniesienia kary śmierci we wszystkich okolicznościach, sporządzony w Wilnie dnia 3 maja 2002 r. (Dz. U. z 2014 r., poz. 1155).

Protokół 6 do Konwencji o ochronie praw człowieka i podstawowych wolności, dotyczący zniesienia kary śmierci, sporządzony w Strasburgu dnia 28 kwietnia 1983 r. (Dz. U. 2001, nr 23, poz. 266).

Powszechna Deklaracja Praw Człowieka, G.A. Res. 217A, at 71, U.N. GAOR, 3d Sess., 1st plen. mtg., U.N. Doc A/810 (10 grudnia 1948).

\section{NETOGRAFIA}

Ostatni wyrok śmierci w PRL. Za co zginął Stanisław Czabański? Fakt 24, http://www.fakt. pl/wydarzenia/polska/ostatni-wyrok-smierci-w-prl-wykonano-na-stanislawie-czabanskim/ ewtfhdm [dostęp: 15.04.2018].

Edykt mediolański, https://pl.wikipedia.org/wiki/Edykt_mediolański [dostęp: 15.04.2018].

FranciszeK (2017). Stanowcze „Nie!” wobec kary śmierci, Gość.pl, https://www.gosc.pl/ doc/4242881.Franciszek-Stanowcze-Nie-wobec-kary-smierci [dostęp: 16.08.2018].

70 lat temu na szubienicy zawist Arthur Greiser. To była ostatnia publiczna egzekucja w Polsce, https://www.tvn24.pl/poznan,43/ostatnia-publiczna-egzekucja-w-polsce-70-lat-od-smierci-a-greisera,659520.html [dostęp: 15.04.2018].

Pademski, S. (2001). Stryczek i kula. Historia kary śmierci w PRL. Gazeta Wyborcza, $11 \mathrm{z}$ dn. 13.01, http://www.archiwum.wyborcza.pl/Archiwum/1,0,1318809,20010113rpdgw,Stryczek _i_kula,.html [dostęp: 15.04.2018].

Parfieniuk, I. (2009). Między marginalizacja a integracją. Wybór jednostkowych strategii akulturacyjnych $i$ ich uwarunkowania. Repetytorium Uniwersytetu w Białymstoku, https:// repozytorium.uwb.edu.pl/jspui/handle/11320/2809 [dostęp: 22.04.2018].

Patterson, K.L. (2006). Acculturation and the Development of Death Penalty Doctrine in the United States, Duke Law Journal 1217-1246, 55, https://scholarship.law.duke.edu/dlj/vol55/ iss6/4 [dostęp: 15.04.2018]. 
The Summa Theologiae of St. Thomas Aquinas (1920). Wyd. II poprawione, http://www.newadvent.org/summa/3064.htm [dostęp: 22.04.2018].

Uglorz, M. (2012). Kara śmierci - refleksja etyczno-teologiczna. Ewangelickie Duszpasterstwo Więzienne, http://www.edwi.pl/?p=382 [dostęp: 24.04.2018].

Wóstowicz, M. (2015). Św. Tomasz z Akwinu - zrozumieć Boga. Religia Deon.pl, https:// www.deon.pl/215/art,117,sw-tomasz-z-akwinu-zrozumiec-boga.html [dostęp: 22.04.2018].

Wytyczne z dnia 3 czerwca 1998 r. w sprawie polityki UE wobec krajów trzecich w zakresie kary śmierci [Council of the European Union, Guidelines to EU policy towards third countries on the death penalty], 29 June 1998, http://www.refworld.org/docid/4705f3d12. html [dostęp: 21.04.2018].

\title{
AKULTURALIZM KARY ŚMIERCI W ŚWIETLE PEDAGOGIKI I TEOLOGII
}

\section{Streszczenie}

Życie ludzkie jest najwyższą wartością w hierarchii dóbr chronionych prawem, zarówno z perspektywy pojedynczego człowieka, jak i całego społeczeństwa, a równocześnie stanowi warunek skorzystania z innych dóbr. Dla jego ochrony nie powinny mieć znaczenia obowiązujący system prawny, religijny, wyznawany światopogląd czy możliwe różnice kulturowe, gdyż prawo do życia przysługuje każdej istocie ludzkiej (nawet przestępcy) z samego faktu bycia człowiekiem. Życie stanowi bowiem jedyne, niepowtarzalne i nieodtwarzalne dobro człowieka. Bez życia nie możemy mówić o człowieku, a bez człowieka wszystko, co ma ludzki charakter, traci sens na zasadzie contradicto in adiecto. Każda istota ludzka ma przyrodzone prawo do życia. Prawo to powinna ochraniać ustawa. Nikt nie może być arbitralnie pozbawiony życia.

Słowa kluczowe: człowiek; akulturacja; akulturalizm; kara śmierci; kara; życie.

\author{
ACCULTURISM OF THE DEATH PENALTY \\ IN THE LIGHT OF PEDAGOGY AND THEOLOGY
}

\section{Summary}

Human life is the highest value in the hierarchy of goods protected by law, both from the perspective of an individual and the whole society, and at the same time it is a condition for taking advantage of other goods. For his protection, the legal, religious, worldviews and possible cultural differences should not be valid, because the right to life is vested in every human being (even criminals) of the very fact of being a human being. Life is the only, unique and unfeasible good of man. Without life, we can not talk about a human being, and without a human being, everything that has a human character loses meaning on the principle of contradicto in adiecto. Every human being has the inherent right to life. This right should protect the law. Nobody can be arbitrarily deprived of life.

Key words: man; acculturation; acculturation; capital punishment; punishment; life. 